REVIEW ARTICLE

\title{
Beta-blockers in Traumatic Brain Injury
}

\author{
Airton Leonardo de Oliveira Manoel ${ }^{1}$, Sandro Rizoli ${ }^{2}$, Ayman El-Menyar ${ }^{3}$, Ruben Peralta ${ }^{4}$, Hassan Al-Thani ${ }^{5}$
}

\begin{abstract}
Severe traumatic brain injury (TBI) is a major public health issue, responsible for high rates of long-term disability and mortality. Although severe TBI is a leading cause of death worldwide, even mild head injuries can adversely impact the functional outcome. It is well described that trauma produces a complex stress response to reestablishing homeostasis. The activation of the stress response (i.e., the hypothalamic-pituitary-adrenal axis and the sympathetic nervous system) leads to the release of glucocorticoids and catecholamines. Although fundamental for survival, the stress response is one of the major players in the development of posttraumatic complications. TBI in particular leads to a fast and intense sympathetic nervous system's activation with huge liberation of both central and peripheral catecholamines, including epinephrine (Epi) and norepinephrine (NE). Since catecholamine levels increase exponentially after TBI, they have been appraised as possible prognostic biomarkers and a target for intervention in this clinical setting. Currently, there is no particular pharmacological treatment available to reduce or limit the progression of secondary brain injury after TBI. However, preliminary data on the use of $\beta$-blockers after TBI have shown promising results. A recent meta-analysis estimated an in-hospital mortality reduction of $65 \%$, while a matched case-control study described that the exposure to a $\beta$-blocker were associated with improved functional outcome. Despite these promising and interesting results, the use of $\beta$-blockage in the acute phase of TBI remains experimental, requiring further evaluation in a well-designed multicenter randomized clinical trial.
\end{abstract}

Keywords: Beta-blockers, Catecholamines, Prognosis, Traumatic brain injury.

Panamerican Journal of Trauma, Critical Care \& Emergency Surgery (2019): 10.5005/jp-journals-10030-1241

\section{Resumo}

A lesão cerebral traumática grave (TCE) é um importante problema de saúde pública, responsável por altas taxas de mortalidade e incapacidade a longo prazo. Embora o TCE grave seja uma das principais causas de morte no mundo, até lesões cranianas leves podem afetar adversamente o resultado funcional. É bem descrito que o trauma produz uma complexa resposta ao estresse para restabelecer a homeostase. A ativação da resposta ao estresse (isto é, o eixo hipotálamo-hipófise-adrenal e o sistema nervoso simpático) leva à liberação de glucocorticóides e catecolaminas. Embora fundamental para a sobrevivência, a resposta ao estresse é um dos principais fatores no desenvolvimento de complicações pós-traumáticas. OTCE, em particular, leva a uma ativação rápida e intensa do sistema nervoso simpático, com grande liberação de catecolaminas centrais e periféricas, incluindo epinefrina (Epi) e noradrenalina (NE). Como os níveis de catecolamina aumentam exponencialmente após o TCE, eles têm sido avaliados como possíveis biomarcadores prognósticos e alvo de intervenção nesse cenário clínico. Atualmente, não existe tratamento farmacológico específico disponível para reduzir ou limitar a progressão da lesão cerebral secundária após oTCE. No entanto, dados preliminares sobre o uso de betabloqueadores após o TCE mostraram resultados promissores. Uma metanálise recente estimou uma redução da mortalidade intra-hospitalar de $65 \%$, enquanto um estudo caso-controle semelhante descreveu que a exposição a beta bloqueador estava associada a um melhor resultado funcional. Apesar desses resultados promissores e interessantes, o uso de beta bloqueio na fase aguda do TCE permanece experimental, exigindo avaliação adicional em um ensaio clínico randomizado multicêntrico bem projetado.

Palabras clave: Beta bloqueadores, Catecolaminas, Prognóstico, Traumatismo cranio-encefálico.

\section{INTRODUCTION}

The catecholamines as outcome markers in an isolated TBI study (the COMA-TBI study) $)^{1}$ have described in a prospective multicenter cohort that TBI patients demonstrated a characteristic pattern of catecholamine release into the peripheral blood over the first 24 hours of injury, which is depicted by a substantial release of Epi and NE in the moments following the trauma (Fig. 1). Patients demonstrated a large peak of catecholamine levels on hospital admission followed by a continuous decrease thereafter.

It is well described that TBI leads to instantaneous and intense activation of sympathetic nervous system with a huge release of both central and peripheral catecholamines. ${ }^{1,2}$ This adaptive phenomenon is fundamental for survival, as a single episode of systolic blood pressure (SBP) below $90 \mathrm{~mm} \mathrm{Hg}$ doubles mortality. ${ }^{3}$ Recently, additional information emerged showing that blood pressure threshold associated with outcome is even higher after TBI. ${ }^{4}$ The brain trauma foundation, therefore, changed its recommendations to "maintaining SBP at $\geq 100 \mathrm{~mm} \mathrm{Hg}$ for patients $50-69$ years old or at $\geq 110 \mathrm{~mm} \mathrm{Hg}$ or above for patients $15-49$ or over 70 years old may be considered to decrease mortality and
${ }^{1}$ Department of Critical Care Medicine, Hospital Paulistano-United Health Group, São Paulo, Brazil

${ }^{2,5}$ Department of Surgery, Hamad General Hospital, Doha, Qatar

${ }^{3}$ Department of Trauma and Vascular Surgery, Hamad General Hospital, Doha, Qatar; Clinical Medicine, Weill Cornell Medical College, Doha, Qatar

${ }^{4}$ Department of Surgery, Trauma Surgery, Hamad General Hospital, Doha, Qatar; Department of Surgery, Universidad Nacional Pedro Henriquez Urena, School of Medicine, Santo Domingo, Dominican Republic

Corresponding Author: Airton Leonardo de Oliveira Manoel, Department of Critical Care Medicine, Hospital Paulistano-United Health Group, São Paulo, Brazil, Phone: +55 113016 1340, e-mail: airtonleo.manoel@gmail.com

How to cite this article: de Oliveira Manoel AL, Rizoli S, et al. Betablockers in Traumatic Brain Injury. Panam J Trauma Crit Care Emerg Surg 2019;8(2):80-90.

Sources of support: The COMA-TBI study was funded by a Research Grant awarded to Dr. Sandro Rizoli by the Physician's Services Incorporation Foundation, Ontario, Canada

Conflict of interest: None

(O) The Author(s). 2019 Open Access This article is distributed under the terms of the Creative Commons Attribution 4.0 International License (https://creativecommons. org/licenses/by-nc/4.0/), which permits unrestricted use, distribution, and non-commercial reproduction in any medium, provided you give appropriate credit to the original author(s) and the source, provide a link to the Creative Commons license, and indicate if changes were made. The Creative Commons Public Domain Dedication waiver (http://creativecommons.org/publicdomain/zero/1.0/) applies to the data made available in this article, unless otherwise stated. 


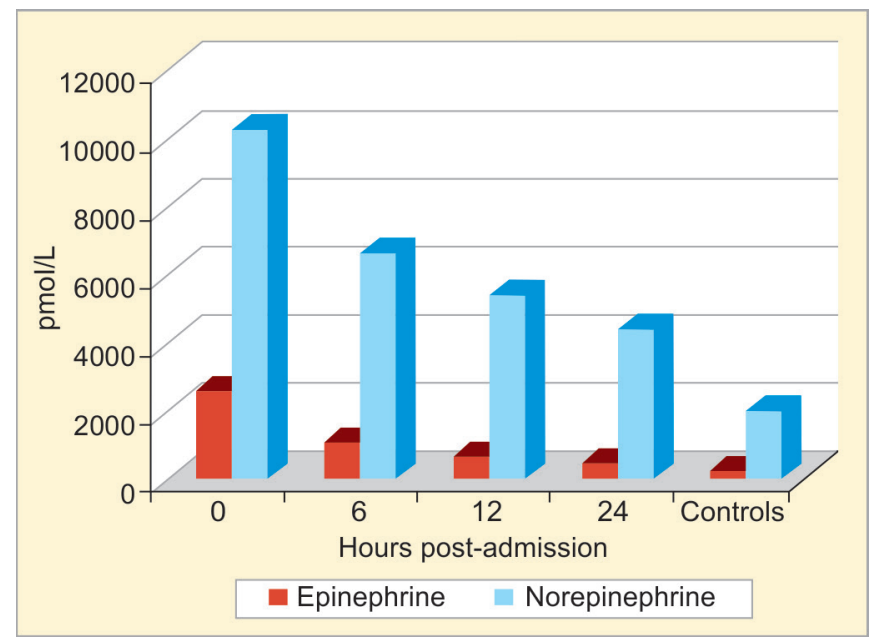

Fig. 1: Median levels of Epi and NE within 24 hours post-admission. Controls had one sample collected and used as the baseline. Controls were 50 healthy volunteers [age $30.3 \pm 7.7$ years (mean \pm SD)], who had their blood collected after a 30-minute resting period. Control participants were excluded if they had any previous history of TBI or comorbidities

improve outcomes." ${ }^{5}$ These recommendations were revised from previous guidelines ${ }^{6}$ due to new evidence arising from a large class II retrospective cohort of moderate to severe TBI patients, which included almost 16,000 patients. Patients were grouped into three age groups as mentioned above, and the results suggested that a cutoff of SBP $<110 \mathrm{~mm} \mathrm{Hg}$ should be considered as hypotension in moderate to severe TBI population. ${ }^{4}$ These results are corroborated by other studies, ${ }^{7-9}$ which also support the decision of the Brain Trauma Foundation to change the hypotension thresholds.

On the contrary, sympathetic nervous system overactivation, through the release of catecholamine and stimulation of $a$ and $\beta$ adrenoreceptors, might produce hypermetabolism, protein catabolism, muscle wasting, and increase cardiac and cerebral metabolic rate of oxygen. ${ }^{10-12}$ Additionally, several studies showed a significant association between high catecholamine levels and worse clinical outcomes, such as longer duration of mechanical ventilation and hospital stay, increased myocardial damage, endocrine abnormalities, and unfavorable long-term functional outcome. ${ }^{13-15}$

In an effort to counterbalance the catecholamine surge, several observational studies have shown that $\beta$-blockage may improve outcome. However, these results require further evaluation in a well-designed multicenter randomized clinical trial. Therefore, this article provides a comprehensive review on the association between catecholamines and the pathophysiology of secondary brain injury after TBI, as well as the potential role of $\beta$-blockage after severe TBI.

\section{Search Strategy}

A systematic review using MEDLINE, EMBASE, and Google Scholar was performed from inception to April 30, 2019. Eligible articles that described the association between catecholamine levels and outcome, as articles that tested the use of $\beta$-blockers after TBI were, searched. The terms "traumatic brain injury" (All Fields) AND "catecholamine" (All Fields) returned 62 articles. Additionally, three recent meta-analyses in this topic were analyzed and their reference lists were scrutinized. Also, the authors own article database was used to retrieve additional articles.

\section{Early Sympathetic Hyperactivity and the Effects Within and OUtside the Brain}

Systemic complications after TBI are common and affect negatively overall outcome, increasing the rates of morbidity and mortality. ${ }^{16,17}$ Zygun et al. ${ }^{16}$ described the effects of nonneurological complications in a cohort of severe TBI. Out of 209 consecutive patients included in the study, 185 (89\%) developed at least one non-neurologic organ dysfunction. The respiratory system was the most common system affected (23\%), followed by the cardiovascular system (18\%), and the coagulation (4\%). The effect of one and two organ failures was significantly associated with mortality (i.e., $40 \%$ and $47 \%$, respectively). These systemic complications may result from direct effect of acute brain injury or as a side effect of therapy employed to optimize cerebral blood flow or to treat increased intracranial pressure. ${ }^{17}$

The massive catecholamine surge is one of the main theories implicated in the development of cerebral and systemic complications, which includes changes in the brain itself, and non-neurological organ failures, including the heart, the lungs, the immune, and coagulation systems (Table 1).

\section{Brain}

An intact blood-brain barrier (BBB) usually avoids the peripheral circulating catecholamines from reaching the brain tissue. ${ }^{18}$ However, the BBB is commonly disrupted following TBI, which may lead to the accumulation of catecholamines in the brain, affecting the cerebral microcirculation and the neuronal function. ${ }^{18}$ The cerebral accumulation of catecholamines decreases the cerebral blood flow by affecting

Table 1: System affected by the sympathetic hyperactivity after TBI

1 The brain - the BBB is commonly disrupted following TBI, which may lead to the accumulation of catecholamines in the brain, affecting the cerebral microcirculation and the neuronal function ${ }^{18}$

2 The heart-patients with acute brain injury commonly present cardiac changes, varying from sinus tachycardia to acute ST segment changes and fatal ventricular arrhythmias. ${ }^{14,15}$ A HsTnT (HsTnT) $\geq 26.5 \mathrm{ng} / \mathrm{L}$ predicts all-causes of mortality. Takotsubo cardiomyopathy, a severe form of acute heart failure, occurs in some cases and it is mainly due to the massive catecholamine release rather than acute coronary syndrome ${ }^{22}$

3 The lungs-are the most commonly affected organ after TBI. Catecholamine-induced pulmonary vasoconstriction increases the pulmonary hydrostatic pressure and the capillaries permeability, which ultimately leads to the accumulation of fluid into the alveoli (i.e., neurogenic pulmonary edema) ${ }^{23}$

4 The immune system-TBI is commonly accompanied by the development of a prominent SIRS, and subsequent antiinflammatory response in an attempt to counterbalance the progress of SIRS. These processes may lead to some degree of immunosuppression, and, consequently, the development of multiple organ failure, and high rates of death ${ }^{63}$

5 The coagulation system - the development of acute coagulopathy in the context of isolated TBI is associated with high rates of mortality. ${ }^{31}$ High catecholamine levels are correlated with endotheliopathy and coagulopathy biomarkers (i.e., procoagulant and hyperfibrinolytic state), which are also associated with unfavorable functional outcome in this case scenario $^{64}$ 
the microcirculation, which, in turn, may lead to ischemia and may worsen the traumatic cerebral edema.

\section{Heart}

Patients with acute brain injury commonly present acute electrocardiographic (ECG) changes, varying from sinus tachycardia to acute ST segment changes and fatal ventricular arrhythmias. ${ }^{14,15}$ Most of the ECG changes are asymptomatic; however, the evidence of myocardial damage is frequently evidenced by elevated biomarker levels, such as troponin. ${ }^{19,20}$ Ayman El-Menyar et al. ${ }^{21}$ showed in a large cohort of 490 intubated TBI patients that highsensitivity troponin $\mathrm{T}$ (HsTnT) is an independent predictor of outcome. A HsTnT $\geq 26.5 \mathrm{ng} / \mathrm{L}$ predicted all-causes of mortality (AUC $0.75,95 \% \mathrm{Cl} 0.699-0.801-80 \%$ sensitivity). Also, patients with a positive HsTnT had a lower Glasgow Coma Scale and were more likely to experience intraventricular hemorrhage and cerebral edema. In some cases, patients may develop a severe form of acute cardiac failure called the Takotsubo cardiomyopathy. This acute form of heart failure is mainly secondary to myocytolysis with band necrosis, induced by the massive catecholamine release rather than the acute coronary syndrome. ${ }^{22}$ Interestingly, some studies demonstrated a mortality reduction by the use of $\beta$-blocker in the group of TBI patients with elevated troponin levels. ${ }^{19,20}$

\section{Lungs}

Lungs are also frequently involved after acute brain injury. The most common pathologies are pneumonia, neurogenic pulmonary edema, pulmonary embolism, and acute respiratory distress syndrome (ARDS). Catecholamine-induced pulmonary vasoconstriction increases the pulmonary hydrostatic pressure and the capillaries permeability, which ultimately leads to the accumulation of fluid into the alveoli (neurogenic pulmonary edema). ${ }^{23}$ This process is also perpetuated by inflammatory mechanisms that are also dependent on catecholamine release. ${ }^{24}$ $\mathrm{NE}$ and neuropeptide $\mathrm{Y}$ that are co-stored in the vesicles in the sympathetic nerve terminations are massively released in the lungs in response to a sympathetic activation. Both mediators play a fundamental role in the genesis of neurogenic pulmonary edema in this clinical scenario, due to their vasoconstrictive activity and by the worsening in the pulmonary vascular permeability. ${ }^{25,26}$ Holland et al. investigated the influence of respiratory failure on outcome after isolated TBI. The authors included 137 mechanically ventilated patients, of whom $31 \%$ developed acute lung injury (ALI) as defined by the old definition by the American-European consensus conference. Mortality in the ALI group (currently defined as mild ARDS) was more than double compared with the group of patients without respiratory failure (38\% vs $15 \%$ ). Additionally, the development of ALI was significantly associated with unfavorable functional outcome according to the Glasgow outcome scale. ${ }^{26}$

\section{Immune System}

The immune system is also activated by catecholamine release after TBI. Dysregulated inflammation may play an important role in the development of non-neurological organ failure after brain injury. ${ }^{27}$ Increased levels of cytokine in the cerebral spinal fluid (CSF) have been found after $\mathrm{TBI}^{28}$ and it appears that these cytokines are delivered into the systemic circulation. ${ }^{29} \mathrm{TBI}$ is commonly accompanied by the development of a prominent systemic inflammatory response syndrome (SIRS) ${ }^{30}$ The inflammatory response may trigger the acute development of acute organ and tissue disfunction. In a vicious cycle, inflammation leads to acute organ and tissue damage, which in turn triggers the release of more inflammatory biomarkers. Therefore, the acute brain injury produces local and systemic inflammation, with subsequent anti-inflammatory response in an attempt to counterbalance the progress of SIRS. Although the compensatory anti-inflammatory response syndrome is fundamental, it may also induce some degree of immunosuppression, and, consequently, the development of additional organ failure.

\section{Coagulation System}

The development of coagulopathy is common after multisystem trauma, but patients may develop acute coagulopathy even in the context of isolated TBI, which is associated with high rates of mortality. ${ }^{31}$ It has been described that high catecholamine levels are correlated with endotheliopathy and coagulopathy biomarkers (procoagulant and hyperfibrinolytic state), which are also associated with unfavorable functional outcome. ${ }^{24}$

\section{Are $\beta$-blockers Protective after TBi?}

Because increased catecholamine levels play a pivotal role in the progression of secondary brain injury, and it is also associated with the development of systemic complications, after TBI, the use of $\beta$-blockers in this scenario has been postulated for decades. Experimental models of propranolol administration, a nonspecific $\beta$-blocker that crosses the BBB, have been shown in a dosedependent fashion to improve cerebral perfusion and glucose metabolism, while decreasing cerebral hypoxia. Additionally, $\beta$-blockage interrupts the $\beta$-adrenergic signaling pathway, which decreases the oxidative and inflammatory stresses, increasing vasodilation, and reducing the heart remodeling. In humans, several meta-analyses, which included mainly observational studies, revealed that the use of $\beta$-blockers after TBI is associated with significant lower mortality rates. ${ }^{32}$

\section{Biological Plausibility-The COMA tBi STUDY}

The COMA-TBI study was a multicenter prospective study that evaluated the association between peripheral catecholamine levels and functional outcome after moderate to severe blunt TBI. A total of 174 patients were included in three-level 1 trauma centers across North America. Patients had their peripheral blood collected to measure Epi and NE levels at admission (baseline) and every 6 hours thereafter in the first 24 hours post-injury. The study demonstrated that raised peripheral catecholamine levels on hospital admission, especially Epi, were independently associated with unfavorable functional outcome (extended Glasgow Outcome Scale (GOSE) 5-8) and mortality after isolated TBI. ${ }^{1}$ Patients displayed a characteristic pattern of catecholamine release into the peripheral blood over the first 24 hours of injury, which was depicted by a substantial release in the moments following the trauma (i.e., a large peak of catecholamine levels on hospital admission) followed by a gradual decrease thereafter (Fig. 1). These catecholamine levels were consistently higher in the TBI patients when compared to healthy volunteers. ${ }^{1}$ More importantly, elevated catecholamine levels on hospital admission were independently associated with unfavorable long-term functional outcome (Fig. 2). These findings add biological plausibility to the possible benefit of $\beta$-blockage after TBI. 


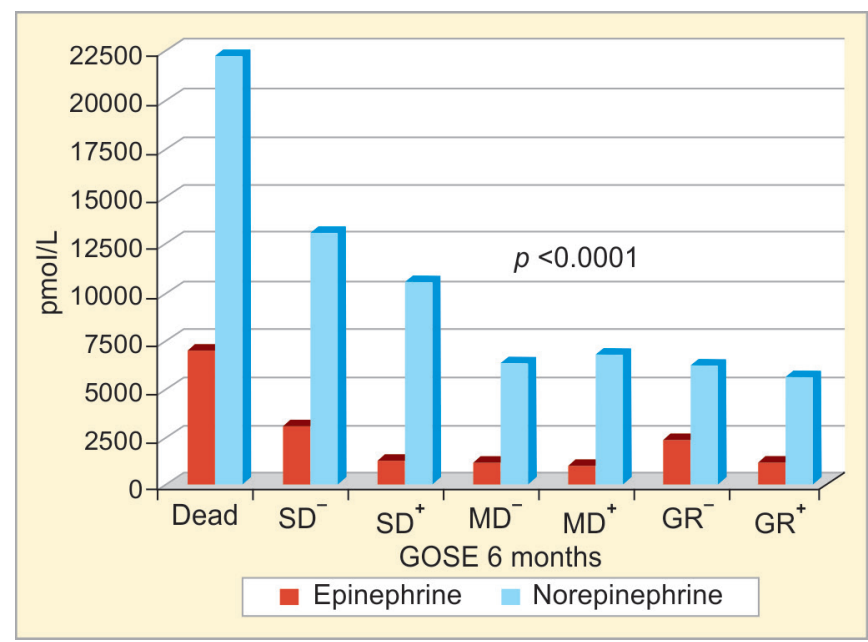

Fig. 2: Correlation of Epi and NE levels (pmol/L) on admission with GOSE categories (Kruskal-Wallis test). There were no patients classified as the vegetative state. $\mathrm{GR}^{-}$, lower good recovery; $\mathrm{GR}^{+}$, upper good recovery; $\mathrm{MD}^{-}$, lower moderate disability; $\mathrm{MD}^{+}$, upper moderate disability; $\mathrm{SD}^{-}$, lower severe disability; $\mathrm{SD}^{+}$, upper severe disability

\section{Relationship between High Catecholamine Levels and Worse Outcomes after TBI}

TBI patients are commonly found to display signs of increased sympathetic nervous system activity, such as hypertension and tachycardia. Likewise, some studies showed that exogenous administration of NE rises the consumption of oxygen, and also increases the respiratory rate, lactic acid production, and blood glucose.

There are several mechanisms that may be implicated in the complex interaction between the sympathoadrenal activation and the brain, which may explain the unfavorable outcome after TBI (Table 2):

- Epi injection during cardiopulmonary resuscitation has deleterious consequences on cerebral microvascular blood flow ${ }^{33,34}$ because it decreases cortical microcirculatory blood flow, which worsens the intensity of cerebral ischemia during cardiopulmonary resuscitation, ${ }^{34}$ and also after the return of spontaneous circulation. ${ }^{33}$

- Sympathoadrenal activation mediates the systemic inflammatory response, ${ }^{35}$ and the development of coagulopathy and endotheliopathy. ${ }^{24}$ Endothelial damage/dysfunction, mostly glycocalyx disruption resulted from sympathoadrenal activation,

Table 2: Why sympathoadrenal over activation may lead to unfavorable outcome after TBI?
(a)
(b)
(c)
(d)
(e)
(f)

is the main driver of coagulopathy and endotheliopathy in this clinical scenario. ${ }^{24}$

- High circulating catecholamine levels are independently associated with these biomarkers of inflammation, endotheliopathy, and coagulopathy in the first 24 hours after brain injury. These biomarkers of coagulopathy and endotheliopathy are associated with unfavorable outcome in isolated TBI patients.

- Increased cardiac demand-the heart can be negatively affected through different mechanisms after acute brain injury, as described above in the section "Early Sympathetic Hyperactivity and the Effects within and outside the Brain"

- Hypermetabolism, protein catabolism, and muscle wastingin other clinical scenarios associated with sympathoadrenal overactivation, such as multiple trauma and severe burn, increased sympathetic system activity is associated with hypermetabolism, altered lipid, and protein metabolism, which cause muscle wasting and loss of lean body mass. ${ }^{10-12}$

- Augmented intracapillary hydrostatic pressure and the development of vasogenic cerebral edema-this topic will be further discussed below in the Lund Protocol section.

\section{Association between $\beta$-blockers Use AND OUTCOME}

We performed a systematic review using MEDLINE, EMBASE, and Google Scholar. Eligible articles that tested the use of $\beta$-blockers after TBI were searched. Only one complete randomized clinical trial was found. The authors randomized 114 hemodynamically stable patients (intervention: 56 , control: 58 ) to receive atenolol (10 mg intravenously four times a day for 3 days followed by $100 \mathrm{mg}$ orally once a day for 4 days) vs placebo. ${ }^{36}$ Nine patients (30\%) in the placebo group vs two patients (7.4\%) in the atenolol group displayed myocardial isoenzyme of creatine kinase (CKMB) levels greater than $3 \%$ of total creatine kinase (CK), which is compatible with acute myocardial injury. No patient in the atenolol group vs $16.7 \%$ of patients in the placebo group had CKMB levels greater than $6 \%$ of total CK, which may be compatible with acute myocardial infarction. Therefore, the use of atenolol was associated with lower likelihood of cardiac events, such as supraventricular tachycardia or ST-segment changes; however, the study was not powered to detect differences in mortality.

Another single-center randomized clinical trial ${ }^{37}$ tested the adrenergic blockage by the use of propranolol (1 mg intravenously every 6 hours for 7 days $)+$ clonidine $(0.1 \mathrm{mg}$ per tube every 12 hours for 7 days), started within 48 hours post-injury vs placebo. The recruitment has been completed, but the study results have not yet been published. According to the results exhibited in the website of ClinicalTrial.gov (Trial Registration: NCT01322048), patients randomized to adrenergic blockage had reduced plasma levels of NE as measured on day 8 compared with the placebo group [median (interquartile range): $962 \mathrm{pg} / \mathrm{mL}$ (508-1471) in the propranolol group vs 714 (391-1257)]. Additionally, mortality was lower in the intervention group [5/21 (23.81\%) in the propranolol group vs $8 / 26(30.77 \%)$ in the placebo]. ${ }^{37}$

Several other cohorts reported the association between the use of $\beta$-blocker and mortality (Table 3). Interestingly, most of the cohorts that evaluated the impact of $\beta$-blockage showed lower adjusted odds of mortality. These studies were combined in different manners in three meta-analyses. The first meta-analysis by Alali et al. included the randomized trial described above plus 8 cohorts. $^{38}$ The 8 retrospective cohorts contained $n=4,782$ 
Table 3: Systematic review

\begin{tabular}{|c|c|c|c|c|}
\hline Study & Patient population & Design & Intervention & Outcomes \\
\hline \multirow[t]{2}{*}{ Ley et al. ${ }^{51}$} & 2,252 patients & $\begin{array}{l}\text { Prospective multicenter } \\
\text { observational study }\end{array}$ & Any $\beta$-blocker & $\begin{array}{l}\beta \text {-blockers were associated } \\
\text { with lower mortality (AOR 0.35; } \\
p<0.001 \text { ) }\end{array}$ \\
\hline & $\begin{array}{l}49.7 \% \text { received } \\
\beta \text {-blocker }\end{array}$ & $\begin{array}{l}15 \text { trauma centers in North } \\
\text { America }\end{array}$ & No protocol described & $\begin{array}{l}\text { Propranolol was superior to other } \\
\beta \text {-blockers (AOR } 0.51, p=0.010 \text { ) }\end{array}$ \\
\hline \multirow[t]{3}{*}{ Patel et al. ${ }^{37}$} & Severe TBI patients & $\begin{array}{l}\text { Single-center, randomized, } \\
\text { double-blinded, placebo- } \\
\text { controlled trial }\end{array}$ & $\begin{array}{l}\text { Propranolol ( } 1 \text { mg intrave- } \\
\text { nously every } 6 \text { hours for } \\
7 \text { days) + clonidine }(0.1 \mathrm{mg} \\
\text { per tube every } 12 \text { hours } \\
\text { for } 7 \text { days); within } 48 \text { hours } \\
\text { post-injury }\end{array}$ & $\begin{array}{l}\text { Reduction in plasma NE level } \\
\text { as measured on day } 8, \text { median } \\
\text { (inter-quartile range): } 962 \mathrm{pg} / \\
\mathrm{mL} \text { (508-1471) in the propranolol } \\
\text { group vs } 714 \text { (391-1257) }\end{array}$ \\
\hline & $\begin{array}{l}21 \text { patients in the } \\
\beta \text {-blocker group }\end{array}$ & & & $\begin{array}{l}\text { All-causes of mortality: interven- } \\
\text { tion group }[5 / 21(23.81 \%)] \text { vs } \\
\text { [8/26 (30.77\%) in the placebo] }\end{array}$ \\
\hline & $\begin{array}{l}26 \text { patients in the } \\
\text { control group }\end{array}$ & & & \\
\hline \multirow[t]{3}{*}{ Ahl et al. ${ }^{41}$} & $\begin{array}{l}362 \text { patients with } \\
\text { severe } T B I\end{array}$ & $\begin{array}{l}\text { Retrospective, matched } \\
\text { case control study from } \\
\text { January 2007-December } \\
2011\end{array}$ & Any $\beta$-blocker & $\begin{array}{l}\text { This is the only study that } \\
\text { describes the association } \\
\text { between } \beta \text {-blocker use and } \\
\text { functional outcome }\end{array}$ \\
\hline & $\begin{array}{l}76(21 \%) \text { patients } \\
\text { received } \beta \text {-blocker }\end{array}$ & & No protocol & $\begin{array}{l}\text { The risk of unfavorable long-term } \\
\text { functional outcome (up to } 12 \\
\text { months after injury) was more } \\
\text { than two-fold without the use } \\
\text { of } \beta \text {-blocker (OR } 2.44,95 \% \mathrm{Cl} \\
1.01-6.03, p=0.03 \text { ) }\end{array}$ \\
\hline & $\begin{array}{l}76 \text { matched pairs } \\
\text { were available for } \\
\text { analysis }\end{array}$ & & & $\begin{array}{l}\text { Mean hospital length of stay was } \\
\text { shorter in the } \beta \text {-blocker cases } \\
\text { (18.0 vs } 26.8 \text { days, } p<0.01 \text { ) }\end{array}$ \\
\hline \multirow[t]{3}{*}{ Ahl et al. ${ }^{43}$} & $\begin{array}{l}545 \text { patients with } \\
\text { severe } T B I\end{array}$ & $\begin{array}{l}\text { Retrospective, matched } \\
\text { case control study from } \\
2007-2011\end{array}$ & Any $\beta$-blocker & $\begin{array}{l}\text { This study describes the associa- } \\
\text { tion between } \beta \text {-blocker use and } \\
\text { the decreased risk of posttrau- } \\
\text { matic depression }\end{array}$ \\
\hline & $\begin{array}{l}80(15 \%) \text { patients } \\
\text { received } \beta \text {-blocker }\end{array}$ & & No protocol & $\begin{array}{l}\text { Twenty-six patients (33\%) in the } \\
\text { non } \beta \text {-blocker group developed } \\
\text { posttraumatic depression vs only } \\
14(18 \%) \text { in the } \beta \text {-blocker group } \\
(p=0.04)\end{array}$ \\
\hline & $\begin{array}{l}80 \text { matched pairs } \\
\text { were analyzed after } \\
\text { propensity matching }\end{array}$ & & & $\begin{array}{l}\text { No significant differences in ICU } \\
\text { (mean days: } 5.8 \text { (SD 10.5) vs } 5.6 \\
\text { (SD 7.2), } p=0.85 \text { ) or hospital } \\
\text { length of stay (mean days: } 21 \\
\text { (SD 21) vs } 21 \text { (SD 20), } p=0.94 \text { ) }\end{array}$ \\
\hline \multirow[t]{3}{*}{ Edavettal et al. ${ }^{52}$} & 214 admissions & Retrospective, 2 years & Any $\beta$-blocker & $\begin{array}{l}\text { Post-injury } \beta \text {-blocker adminis- } \\
\text { tration reduces mortality, but } \\
\text { preinjury } \beta \text {-blocker does not }\end{array}$ \\
\hline & $\begin{array}{l}112(52 \%) \text { had no } \\
\beta \text {-blocker use } 46 \\
(21 \%) \text { were on pre- } \\
\text { injury } \beta \text {-blocker }\end{array}$ & & No protocol & \\
\hline & $\begin{array}{l}94(44 \%) \text { were on } \\
\text { post-injury } \beta \text {-blocker }\end{array}$ & & & \\
\hline Murry et al. ${ }^{53}$ & $\begin{array}{l}28 \text { moderate-to- } \\
\text { severe } \mathrm{TBI}\end{array}$ & $\begin{array}{l}\text { Prospective interventional, } \\
\text { non-randomized study } \\
\text { March 2010-August } 2013\end{array}$ & $\begin{array}{l}\text { Propranolol } 1 \text { mg intrave- } \\
\text { nous every } 6 \text { hours starting } \\
\text { within } 12 \text { hours of ICU } \\
\text { admission for a minimum of } \\
48 \text { hours }\end{array}$ & $\begin{array}{l}\text { Mortality rates were ( } 10 \% \text { vs } \\
10.7 \%, p=0.9 \text { ), propranolol vs } \\
\text { control group, respectively }\end{array}$ \\
\hline
\end{tabular}


Contd...

\begin{tabular}{|c|c|c|c|c|}
\hline Study & Patient population & Design & Intervention & Outcomes \\
\hline & $\begin{array}{l}18(64 \%) \text { patients } \\
\text { received propranolol }\end{array}$ & $\begin{array}{l}\text { Emergency Department, } \\
\text { Glasgow Coma Scale was } \\
\text { lower in control (4.2 vs } \\
10.7, p<0.01 \text { ) }\end{array}$ & & $\begin{array}{l}\text { ICU LOS ( } 15.4 \text { vs } 30.4 \text { days, } \\
p=0.02 \text { ) and hospital LOS ( } 10 \text { vs } \\
19.1 \text { days, } p=0.05 \text { ) were lower in } \\
\text { the propranolol group }\end{array}$ \\
\hline & $\begin{array}{l}10(36 \%) \text { patients } \\
\text { did not receive } \\
\text { propranolol }\end{array}$ & & & \\
\hline \multirow[t]{3}{*}{ Zangbar et al. ${ }^{54}$} & $\begin{array}{l}356 \text { severe blunt TBI } \\
\text { patients }\end{array}$ & $\begin{array}{l}\text { Retrospective single } \\
\text { level I trauma center from } \\
\text { 2007-2013 }\end{array}$ & Any $\beta$-blocker & $\begin{array}{l}\text { Metoprolol group displayed } \\
\text { higher survival rates ( } 78 \% \text { vs } 68 \% \text {; } \\
p=0.04 \text { ) }\end{array}$ \\
\hline & $\begin{array}{l}178(50 \%) \text { received } \\
\text { metoprolol }\end{array}$ & $\begin{array}{l}\text { Propensity-matched } \\
\text { cohort }\end{array}$ & $91.3 \%$ received metoprolol & \\
\hline & $\begin{array}{l}178(50 \%) \text { received no } \\
\beta \text {-blocker }\end{array}$ & & No protocol & \\
\hline \multirow[t]{3}{*}{ Ko et al. ${ }^{55}$} & $\begin{array}{l}440 \text { patients with } \\
\text { moderate-to-severe } \\
\text { TBI }\end{array}$ & $\begin{array}{l}\text { Retrospective analysis of a } \\
\text { prospective database from } \\
\text { a single Level I trauma } \\
\text { center from January 1, } \\
\text { 2013-May 31, } 2015\end{array}$ & $\begin{array}{l}\text { Propranolol } 1 \text { mg IV every } 6 \\
\text { hours started within } 24 \text { hour } \\
\text { of admission }\end{array}$ & $\begin{array}{l}\text { Propranolol started within } 24 \\
\text { hour of admission was indepen- } \\
\text { dently associated with lower } \\
\text { mortality (AOR } 0.25, p=0.012 \text { ) }\end{array}$ \\
\hline & $\begin{array}{l}109(25 \%) \text { received } \\
\text { propranolol }\end{array}$ & & & \\
\hline & $\begin{array}{l}331(75 \%) \text { did not } \\
\text { received propranolol }\end{array}$ & & & \\
\hline \multirow[t]{3}{*}{ Mohseni et al. ${ }^{56}$} & $\begin{array}{l}874 \text { isolated severe } \\
\text { TBI patients }\end{array}$ & $\begin{array}{l}\text { Retrospective single aca- } \\
\text { demic trauma center from } \\
\text { January 2007-December } \\
2011\end{array}$ & Any $\beta$-blocker & $\begin{array}{l}\text { No exposure to } \beta \text {-blockers was } \\
\text { associated with a } 5 \text {-fold increased } \\
\text { risk of in-hospital mortality (AOR } \\
5.0, \mathrm{Cl} 95 \% 2.7-8.5, p=0.001 \text { ), } \\
\text { regardless the type of } \beta \text {-blocker } \\
\text { used }\end{array}$ \\
\hline & $\begin{array}{l}287(33 \%) \text { were } \\
\text { exposed to } \beta \text {-blocker }\end{array}$ & & No protocol & $\begin{array}{l}\text { Patients naïve to } \beta \text {-blockers } \\
\text { (no preinjury use o } \beta \text {-blocker) } \\
\text { displayed higher risk of mortal- } \\
\text { ity (AOR } 3.0 \text { CI } 95 \% 1.2-7.1 \text {, } \\
p=0.015 \text { ) }\end{array}$ \\
\hline & $\begin{array}{l}587(67 \%) \text { did not } \\
\text { received } \beta \text {-blocker }\end{array}$ & & & \\
\hline \multirow[t]{3}{*}{ Schroeppel et al. ${ }^{50}$} & 1,755 TBI patients & $\begin{array}{l}\text { Retrospective single level } \\
\text { I trauma center January } \\
\text { 2008-December } 2011\end{array}$ & Any $\beta$-blocker & $\begin{array}{l}\text { Lower mortality in the proprano- } \\
\text { lol group ( } 3 \% \text { vs } 15 \%, p=0.002 \text { ) }\end{array}$ \\
\hline & $\begin{array}{l}427(24 \%) \text { received } \\
\beta \text {-blocker }\end{array}$ & & No protocol & $\begin{array}{l}\text { Adjusted odds ratio, } 0.199 ; 95 \% \\
\text { confidence interval, } 0.04-0.920 \text { ) }\end{array}$ \\
\hline & $\begin{array}{l}78(4 \%) \text { received } \\
\text { propranolol }\end{array}$ & & & \\
\hline \multirow[t]{2}{*}{ Mohseni et al. ${ }^{57}$} & $\begin{array}{l}662 \text { isolated severe } \\
\text { TBI }\end{array}$ & Retrospective, 5 years & Any $\beta$-blocker & $\begin{array}{l}\text { Patients exposed to } \beta \text {-blocker vs } \\
\text { no } \beta \text {-blocker experienced } 13 \% \\
\text { and } 22 \% \text { mortality, respectively } \\
(p=0.01) \text {, but } \beta \text {-blocker had a } \\
\text { higher rate of infectious compli- } \\
\text { cations ( } 30 \% \text { vs } 19 \%, p=0.04 \text { ) }\end{array}$ \\
\hline & $\begin{array}{l}158(25 \%) \text { were } \\
\text { exposed to } \beta \text {-blocker }\end{array}$ & $\begin{array}{l}\text { Stratification by preinjury } \\
\text { BB exposure }\end{array}$ & No protocol & \\
\hline \multirow[t]{2}{*}{ Bukur et al. ${ }^{58}$} & 2,446 isolated TBI & $\begin{array}{l}\text { Retrospective single } \\
\text { academic level I trauma } \\
\text { center from between July } \\
\text { 1998-December } 2009\end{array}$ & Any $\beta$-blocker & $\begin{array}{l}\text { Only Asian and Hispanic descent } \\
\text { revealed significantly improved } \\
\text { outcomes with } \beta \text {-blockers used }\end{array}$ \\
\hline & $\begin{array}{l}\text { Hispanic (60\%), } 35 \% \\
\text { were on } \beta \text {-blocker }\end{array}$ & & No protocol & \\
\hline
\end{tabular}


Contd...

\begin{tabular}{|c|c|c|c|c|}
\hline Study & Patient population & Design & Intervention & Outcomes \\
\hline & $\begin{array}{l}\text { Whites ( } 21 \%), 36 \% \\
\text { were on } \beta \text {-blocker }\end{array}$ & & & \\
\hline & $\begin{array}{l}\text { Asians ( } 11 \%), 35 \% \\
\text { were on } \beta \text {-blocker }\end{array}$ & & & \\
\hline & $\begin{array}{l}\text { African Americans } \\
(8 \%), 34 \% \text { were on } \\
\beta \text {-blocker }\end{array}$ & & & \\
\hline \multirow[t]{3}{*}{ Schroeppel et al. ${ }^{59}$} & $\begin{array}{l}2,601 \text { blunt TBI } \\
\text { patients }\end{array}$ & $\begin{array}{l}\text { Retrospective single level } \\
\text { I trauma center was from } \\
\text { June 2003-December } \\
2007\end{array}$ & Any $\beta$-blocker & $\begin{array}{l}\text { Mortality reduction of } 65 \% \text { by } \\
\text { the use of a } \beta \text {-blocker (odds } \\
\text { ratio, } 0.347 \text {; confidence interval, } \\
0.246-0.490 \text { ) }\end{array}$ \\
\hline & $\begin{array}{l}506(20 \%) \text { received a } \\
\beta \text {-blocker }\end{array}$ & & No protocol & \\
\hline & $\begin{array}{l}2095(80 \%) \text { did not } \\
\text { received any } \beta \text {-blocker }\end{array}$ & & & \\
\hline \multirow[t]{4}{*}{ Salim et al. ${ }^{19}$} & $\begin{array}{l}420 \text { severe blunt TBI } \\
\text { patients who had } \\
\text { serial serum troponin } \\
\text { (Tnl) test }\end{array}$ & $\begin{array}{l}\text { Retrospective single level } \\
\text { I trauma center from Janu- } \\
\text { ary 1998-December } 2005\end{array}$ & Any $\beta$-blocker & $\begin{array}{l}\beta \text {-Blocker was associated with } \\
\text { lower mortality in TBI patients } \\
\text { with Tnl elevation (OR: } 0.38 ; 95 \% \\
\text { Cl: } 0.15,0.87, p=0.03 \text { ) }\end{array}$ \\
\hline & $\begin{array}{l}125(29.8 \%) \text { had } \\
\text { Tnl elevation on } \\
\text { admission }\end{array}$ & & No protocol & \\
\hline & $\begin{array}{l}91(21.7 \%) \text { patients } \\
\text { received a } \beta \text {-blocker }\end{array}$ & & & \\
\hline & $\begin{array}{l}22(5 \%) \text { patients with } \\
\text { elevated Tnl received } \\
\text { a } \beta \text {-blocker }\end{array}$ & & & \\
\hline \multirow[t]{3}{*}{ Inaba et al. ${ }^{60}$} & $\begin{array}{l}1,156 \text { patients with } \\
\text { isolated head injury }\end{array}$ & Retrospective from July & Any $\beta$-blocker & $\begin{array}{l}\text { Adjusted odds ratio for mortal- } \\
\text { ity }=0.54 ; 95 \% \mathrm{Cl}, 0.33-0.91 ; p= \\
0.01) . \text { Elderly patients ( } 55 \text { years } \\
\text { or older) with severe head injury } \\
\text { (abbreviated injury score } \geq 4 \text { ) } \\
\text { had a mortality of } 28 \% \text { ( } \beta \text {-blocker } \\
\text { group) vs } 60 \% \text { (control group) }\end{array}$ \\
\hline & $\begin{array}{l}203(18 \%) \text { received } \\
\beta \text {-blocker }\end{array}$ & 1998-December 2005 & No protocol & \\
\hline & $\begin{array}{l}953(82 \%) \text { did not } \\
\text { received } \beta \text {-blocker }\end{array}$ & & & \\
\hline \multirow[t]{4}{*}{ Cotton et al. ${ }^{61}$} & $\begin{array}{l}420 \text { patients with } \\
\text { severe TBI }\end{array}$ & $\begin{array}{l}\text { Retrospective from Janu- } \\
\text { ary 2004-March } 2005\end{array}$ & $\begin{array}{l}\text { Any } \beta \text {-blocker received for } 2 \\
\text { or more consecutive days }\end{array}$ & $\begin{array}{l}\text { Mortality in the } \beta \text {-blocker was } \\
5.1 \% \text { vs } 10.8 \% \text { in the control } \\
\text { group ( } p=0.036)\end{array}$ \\
\hline & $\begin{array}{l}174(42 \%) \text { patients } \\
\text { received } \beta \text {-blocker }\end{array}$ & & & $\begin{array}{l}\text { Adjusted incidence rate ratio of } \\
\text { mortality for } \beta \text {-blocker exposure }= \\
0.29(95 \% \mathrm{Cl})\end{array}$ \\
\hline & $\begin{array}{l}246(58 \%) \text { patients } \\
\text { did not receive } \\
\beta \text {-blocker }\end{array}$ & & & \\
\hline & $\begin{array}{l}\text { Patients with length } \\
\text { of stay }<4 \text { or }>30 \\
\text { days were excluded }\end{array}$ & & & \\
\hline Riordan et al. ${ }^{65}$ & $\begin{array}{l}446 \text { severe TBI } \\
\text { patients }\end{array}$ & $\begin{array}{l}\text { Retrospective, from } \\
\text { December 2000-October } \\
2005\end{array}$ & Any $\beta$-blocker & $\begin{array}{l}\beta \text {-Blocker exposure was associated } \\
\text { with improved survival, especially } \\
\text { to early } \beta \text {-blocker exposure and } \\
\text { patients with cardiac uncoupling } \\
\text { (percent of time that } 5 \text {-minute } \\
\text { heart rate standard deviation was } \\
\text { between } 0.3 \text { bpm and } 0.6 \text { bpm on } \\
\text { post-injury day 1) }\end{array}$ \\
\hline
\end{tabular}

Contd... 
Contd...

\begin{tabular}{|c|c|c|c|c|}
\hline Study & Patient population & Design & Intervention & Outcomes \\
\hline & $\begin{array}{l}141(29 \%) \text { received } \\
\beta \text {-blocker }\end{array}$ & & No protocol & \\
\hline \multirow[t]{3}{*}{ Arbabi et al. ${ }^{62}$} & $\begin{array}{l}4,117 \text { trauma } \\
\text { patients, including TBI } \\
\text { patients }\end{array}$ & $\begin{array}{l}\text { Retrospective cohort of } \\
\text { trauma patients admitted } \\
\text { to a single level I center }\end{array}$ & Any $\beta$-blocker & $\begin{array}{l}\text { Odds ratio for fatal outcome was } \\
0.3(p<0.001) \text { for patients on } \\
\beta \text {-blocker }\end{array}$ \\
\hline & $\begin{array}{l}303(7 \%) \text { received } \\
\beta \text {-blocker }\end{array}$ & & No protocol & $\begin{array}{l}\text { Decreased risk of death was more } \\
\text { prominent in TBI patients }\end{array}$ \\
\hline & $\begin{array}{l}45 \% \text { of patients } \\
\text { were on preinjury } \\
\beta \text {-blocker }\end{array}$ & & & \\
\hline \multirow[t]{2}{*}{ Martin et al. ${ }^{20}$} & 1,081 patients & Retrospective, 5 years & Any $\beta$-blocker & $\begin{array}{l}\text { Among patients with an increased } \\
\text { troponin level, mortality was } \\
\text { reduced by } 50 \% \text { in the group of } \\
\beta \text {-blocker ( } 38 \text { vs } 16 \% ; p<0.01 \text { ) }\end{array}$ \\
\hline & $\begin{array}{l}29 \% \text { had increased } \\
\text { troponin }\end{array}$ & & No protocol & \\
\hline Cruickshank et al. ${ }^{36}$ & $\begin{array}{l}114 \text { patients (inter- } \\
\text { vention: } 56 \text {, control: } \\
58 \text { ) }\end{array}$ & Randomized clinical trial & $\begin{array}{l}\text { Atenolol } 10 \mathrm{mg} \text { IV every } 6 \mathrm{~h} \\
\text { for } 3 \mathrm{~d} \text { then } 100 \mathrm{mg} \text { PO OD } \\
\text { for } 4 \mathrm{~d} \text { vs matching placebo }\end{array}$ & $\begin{array}{l}\text { Lower risk of high CK-MB (i.e., } \\
>3 \% \text { of total CK) level ( } 2 / 27 \text { vs } \\
\text { 9/30); similar noradrenaline levels; } \\
\text { lower risk of supraventricular } \\
\text { tachycardia ( } 6 / 56 \text { vs } 28 / 58) ; \\
\text { lower risk of ST/T wave changes } \\
\text { (15/56 vs } 26 / 58), \text { No significant } \\
\text { difference in other outcomes: } \\
\text { hypotension ( } 5 / 56 \text { vs } 2 / 58) \text {, } \\
\text { bradycardia }(6 / 56 \text { vs } 6 / 58) \text { heart } \\
\text { failure }(0 / 56 \text { vs } 0 / 58) \text {, and } \\
\text { bronchospasm }(1 / 56 \text { vs } 0 / 58)\end{array}$ \\
\hline
\end{tabular}

patients and "demonstrated that exposure to $\beta$-blockers after TBI was associated with a reduction in the adjusted odds of in-hospital mortality by $65 \%$ (pooled adjusted odds ratio 0.35 ; 95\% Cl 0.27-0.45)." The same author updated this meta-analysis, which included one additional cohort. The authors found that the "exposure to $\beta$-blockers after TBI was associated with a reduction in in-hospital mortality (pooled OR 0.39, 95\% Cl: 0.27-0.56; $\perp^{2} 1 / 4$ $65 \%, p<0.00001) " .39$ Finally, Chen et al. performed a systematic review and meta-analysis that included 13 cohorts with a total of 15,734 cases. Once again $\beta$-blocker use was associated with reduced odds of in-hospital mortality (OR 0.33; 95\% Cl 0.27-0.40; $p<0.001$ ). However, in this last meta-analysis, the use of $\beta$-blocker was associated with higher rates of adverse events, such as increased infection (OR 2.01; 95\% Cl 1.50-2.69; $p<0.001)$, longer length of stay $(\mathrm{MD}=7.40 ; 95 \% \mathrm{Cl}=4.39,10.41 ; p<0.001)$, ICU stay $(\mathrm{MD}=$ $3.52 ; 95 \% \mathrm{Cl}=1.56,5.47 ; p<0.001)$, and longer period of ventilator support $(\mathrm{MD}=2.70 ; 95 \% \mathrm{Cl}=1.81,3.59 ; p<0.001) .{ }^{40}$

\section{Association between $\beta$-blocker Use and Functional Outcome}

One matched case-control study described the association of $\beta$-blocker and functional outcome. Ahl et al. ${ }^{41}$ were the first to study the association between the use of $\beta$-blockers and the long-term functional outcome, including the development of posttraumatic depression. In a retrospective-matched case-control study, the authors included 76 TBI patients who received a $\beta$-blocker started within 48 hours of hospital admission and continued until discharge. The cases were matched with 76 pairs using the propensity score. The risk of unfavorable long-term functional outcome, defined as a
Glasgow outcome scale $\leq 3$, was more than two-fold in the control group (OR 2.44, 95\% Cl 1.01-6.03, $p=0.03$ ). Also, $\beta$-blocker cases had a shorter length hospital of stay (18.0 vs 26.8 days, $p<0.01)$. This is the only study that describes the association between $\beta$-blocker use and functional outcome after TBI.

The same group of authors describes the association between $\beta$-blocker use and the development of posttraumatic depression. ${ }^{42}$ Eighty patients received $\beta$-blocker and were matched with 80 pairs by propensity matching. Twenty-six patients (33\%) in the non $\beta$-blocker group developed posttraumatic depression vs only 14 $(18 \%)$ in the $\beta$-blocker group $(p=0.04)$. Also, preadmission $\beta$-blocker use was associated with a reduced risk of depression. ${ }^{43}$

\section{Therapy of Vasogenic Cerebral Edema Based on Hemodynamic Principles for Brain Volume Regulation-The Lund Protocol}

Other proposed mechanism of brain injury due to sympathoadrenal activation is the increase in the hydrostatic capillary pressure, which leads to the transcapillary fluid extravasation and the formation of interstitial cerebral edema. ${ }^{44}$

Medical therapy to control elevated intracranial pressure include (1) tracheal intubation with ventilation to achieve normocapnia, (2) sedation + analgesia to achieve a calm/motionless state, (3) cerebrospinal fluid drainage through an external ventricular drain, (4) hyperosmolar therapy (i.e., mannitol or hypertonic saline), and, (5) finally, the rescue therapies such as hyperventilation to induce hypocapnia, induced hypothermia, decompressive craniectomy, and metabolic suppression with barbiturate-induced coma. ${ }^{45}$ 
However, all those described therapies are associated with adverse effects. ${ }^{46-48}$ Additionally, promising rescue interventions such as induced hypothermia ${ }^{47}$ and decompressive craniectomy ${ }^{48}$ did not result in outcomes better than medical therapy alone. Actually, in the RESCUEicp Trial, decompressive craniectomy was associated with higher rates of unfavorable functional outcome than medical therapy. ${ }^{48}$

Because medical therapy to control intracranial pressure is associated with adverse effects and may impact negatively outcome, Asgeirsson et al. ${ }^{49}$ developed a clinical protocol to prevent/treat traumatic brain edema based on the theory that hydrostatic capillary pressure and colloid osmotic pressure are fundamentally involved in transcapillary fluid extravasation and the formation of interstitial cerebral edema. Hydrostatic capillary pressure was decreased by the use of an alfa ${ }_{2}$ agonist and a $\beta_{1}$ -blocker (i.e., clonidine and metoprolol, respectively). Additionally, the authors added dihydroergotamine as a precapillary vasoconstrictor to reduce even further the hydrostatic capillary pressure, and also to reduce intracranial blood volume. Out of 11 comatose patients with predicted unfavorable functional outcome, 2 died (18\%), while 9 patients (82\%) survived with good recovery or moderate disability. This was one of the first descriptions of the use of $\beta$-blocker in the management of severe TBI, with promising results. $^{49}$

\section{Does the Type of $\beta$-Blocker Matter?}

The pharmacokinetic and pharmacodynamics of each specific $\beta$-blockers, especially regarding their ability to cross the BBB, should be taken into consideration when choosing the appropriate agent. For example, propranolol is a nonselective $\beta$-blocker that crosses the $\mathrm{BBB}$, with enteral and intravenous formulation. Interestingly, Schroeppe ${ }^{50}$ in a retrospective cohort study found that patients who received $\beta$-blockers had a higher mortality rates (13\% vs $6 \%$, $p<0.001$ ); however, mortality was lower in patients who received propranolol ( $3 \%$ vs $15 \%, p=0.002$ ). These results have been replicated by Ley et al., who showed in a prospective multicenter observational study in 15 trauma centers in North America that propranolol might be superior to other beta blockers.

Unfortunately, most of the cohort studies described in Table 2 did not have a specific protocol regarding the type or dose of $\beta$-blocker. Some exception needs to be commented: (1) the randomized trial by Cruickshank et al. discussed above used atenolol $10 \mathrm{mg}$ IV QID for 3 days followed by $100 \mathrm{mg}$ PO once a day for 4 days; (2) the Lund Protocol described the association of thiopentone (0.5-3 mg/kg/hour) adjusted to a delta-wave pattern on the EEG with continuous infusion of metoprolol (max. $0.3 \mathrm{mg} / \mathrm{kg}$ per $24 \mathrm{hour}$ ) and clonidine (max. $8.0 \mathrm{mg} / \mathrm{kg}$ per 24 hour); (3) other studies used propranolol in different ways, such as Patel et al. [propranolol $1 \mathrm{mg}$ intravenously every 6 hour for 7 days) + clonidine ( $0.1 \mathrm{mg}$ per tube every 12 hours for 7 days), within 48 hours post-injury] or Murray et al. (propranolol $1 \mathrm{mg}$ intravenous every 6 hours starting within 12 hours of ICU admission for a minimum of 48 hours).

\section{Conclusion}

Catecholamine surge after TBI is common and $\beta$-blockage has shown promising results. There is an important signal from several meta-analysis showing a significant reduction in mortality by the use of $\beta$-blocker after TBI. However, important uncertainty remains in the field, which needs to be answered, such as the best type (e.g., selective vs nonselective) and the regimen of $ß$-blocker to be used (i.e., dose, moment of treatment initiation, and duration). High catecholamine levels after TBI is associated with worse outcome, and the use of $\beta$-blocker may reduce mortality and improve long-term outcome; however, these benefits must be adequately evaluated in a large multicenter clinical trial. Additionally, cardiac biomarkers may be used to stratify patients at higher risk that may benefit more by the use of $\beta$-blockers.

\section{References}

1. Rizoli SB, Jaja BNR, et al. Catecholamines as outcome markers in isolated traumatic brain injury: the COMA-TBI study. Critical Care 2017;21(1):1-10. DOI: 10.1186/s13054-017-1620-1626.

2. Woolf PD, Hamill RW, et al. The predictive value of catecholamines in assessing outcome in traumatic brain injury. J Neurosurg 1987;66(6):875-882. DOI: 10.3171/jns.1987.66.6.0875.

3. Chesnut RM, Marshall SB, et al. Early and late systemic hypotension as a frequent and fundamental source of cerebral ischemia following severe brain injury in the Traumatic Coma Data Bank. Acta Neurochir Suppl (Wien) 1993;59:121-125.

4. Berry C, Ley EJ, et al. Redefining hypotension in traumatic brain injury. Injury 2012;43(11):1833-1837. DOI: 10.1016/j.injury.2011.08.014.

5. Carney N, Totten AM, et al. Guidelines for the Management of Severe Traumatic Brain Injury. Neurosurgery 2017 Jan 1;80(1):6-15. DOI: 10.1227/NEU.0000000000001432.

6. Brain Trauma Foundation, American Association of Neurological Surgeons, Congress of Neurological Surgeons. Guidelines for the management of severe traumatic brain injury. J Neurotrauma 2007;24(Suppl. 1)):S1-S106. DOI: 10.1089/neu.2007.9999.

7. Brenner M, Stein DM, et al. Traditional systolic blood pressure targets underestimate hypotension-induced secondary brain injury. J Trauma 2012;72(5):1135-1139. DOI: 10.1097/TA.0b013e31824af90b.

8. Murray GD, Butcher I, et al. Multivariable Prognostic Analysis in Traumatic Brain Injury: Results from The IMPACT Study. J Neurotrauma 2007;24(2):329-337. DOI: 10.1089/neu.2006.0035.

9. Spaite DW, Hu C, et al. Mortality and Prehospital Blood Pressure in Patients With Major Traumatic Brain Injury. JAMA Surg December 2016; 1-9. DOI: 10.1001/jamasurg.2016.4686.

10. Dunser MW, Ruokonen E, et al. Association of arterial blood pressure and vasopressor load with septic shock mortality: a post hoc analysis of a multicenter trial. Crit Care 2009;13(6):R181-R181. DOI: 10.1186/ cc8167.

11. Herndon DN, Hart DW, et al. Reversal of Catabolism by Beta-Blockade after Severe Burns. N Engl J Med 2001;345(17):1223-1229. DOI: 10.1056/NEJMoa010342.

12. Diaz EC, Herndon DN, et al. Effects of pharmacological interventions on muscle protein synthesis and breakdown in recovery from burns. Burns 2015;41(4):649-657. DOI: 10.1016/j.burns.2014.10.010.

13. Hammerle AF, Hackl JM, et al. The activity of the sympathetic nervous system following severe head injury. Intensive Care Med 1980;6(3):169. DOI: 10.1007/BF01757299.

14. McLeod AA, Neil-Dwyer G, et al. Cardiac sequelae of acute head injury. Br Heart J 1982;47(3):221-226. DOI: 10.1136/hrt.47.3.221.

15. Larremore T, Markovchick V. Cardiac sequelae of acute head injury. Br Heart J 1983;49(1):101-102. DOI: 10.1136/hrt.49.1.101.

16. Zygun DA, Kortbeek JB, et al. Non-neurologic organ dysfunction in severe traumatic brain injury*. Crit Care Med 2005;33(3):654-660. DOI: 10.1097/01.CCM.0000155911.01844.54.

17. Zygun D. Non-neurological organ dysfunction in neurocritical care: impact on outcome and etiological considerations. Curr Opin Crit Care 2005;11(2):139-143. DOI: 10.1097/01.ccx.0000155356.86241.c0.

18. Clifton GL, Ziegler MG, et al. Circulating catecholamines and sympathetic activity after head injury. Neurosurgery 1981;8(1):10-14. DOI: 10.1227/00006123-198101000-00003.

19. Salim A, Hadjizacharia $P$, et al. Significance of Troponin Elevation After Severe Traumatic Brain Injury. J Trauma 2008;64(1):46-52. DOI: 10.1097/TA.0b013e31815eb15a. 
20. Martin M, Mullenix $P$, et al. Troponin Increases in the Critically Injured Patient: Mechanical Trauma or Physiologic Stress? J Trauma November 2005; 1086-1091. DOI: 10.1097/01.ta.0000190249.19668.37.

21. El-Menyar $A, A \operatorname{sim} M$, et al. Predictive value of positive high-sensitivity troponin T in intubated traumatic brain injury patients. J Neurosurg 2017;129(6):1541-1549. DOI: 10.3171/2017.7.JNS17675.

22. Akashi YJ, Goldstein DS, et al. Takotsubo Cardiomyopathy. Circulation 2008;118(25):2754-2762. DOI: 10.1161/CIRCULATIONAHA.108.767012.

23. Smith WS, Matthay MA. Evidence for a hydrostatic mechanism in human neurogenic pulmonary edema. Chest 1997;111(5):1326-1333. DOI: 10.1378/chest.111.5.1326.

24. Di Battista AP, Rizoli SB, et al. Sympathoadrenal Activation is Associated with Acute Traumatic Coagulopathy and Endotheliopathy in Isolated Brain Injury. Shock May 2016; 1-32. DOI: 10.1097/ SHK.0000000000000642.

25. Davidson JT, Charuzi I. Epinephrine-induced changes in the pulmonary pressure-volume curve of the intact and hypovolemic rabbit. Chest 1973;63(2):250-253. DOI: 10.1378/chest.63.2.250.

26. Ducker TB, Simmons RL. Increased intracranial pressure and pulmonary edema. 2. The hemodynamic response of dogs and monkeys to increased intracranial pressure. J Neurosurg 1968;28(2):118-123. DOI: 10.3171/jns.1968.28.2.0118.

27. Ley EJ, Clond MA, et al. $\beta$-Adrenergic receptor inhibition affects cerebral glucose metabolism, motor performance, and inflammatory response after traumatic brain injury. J Trauma Acute Care Surg 2012;73(1):33-40. DOI: 10.1097/TA.0b013e31825a769b.

28. Bell MJ, Kochanek PM, et al. Comparison of the interleukin- 6 and interleukin-10 response in children after severe traumatic brain injury or septic shock. Acta Neurochir Suppl 1997;70:96-97.

29. McKeating EG, Andrews PJ, et al. Transcranial cytokine gradients in patients requiring intensive care after acute brain injury. $\mathrm{Br} J$ Anaesth 1997;78(5):520-523. DOI: 10.1093/bja/78.5.520.

30. Jacome T, Tatum D. Systemic Inflammatory Response Syndrome (SIRS) Score Independently Predicts Poor Outcome in Isolated Traumatic Brain Injury. Neurocrit Care May 2017;1-7. DOI: 10.1007/s12028-0170410-y.

31. de Oliveira Manoel AL, Neto AC, et al. Traumatic Brain Injury Associated Coagulopathy. Neurocrit Care 2014;22(1):34-44. DOI: 10.1007/s12028-014-0026-4.

32. El-Menyar A. Beta Blockers Therapy In Traumatic Brain Injury. J Trauma Acute Care Surg February 2018;1-8. DOI: 10.1097/ TA.0000000000001865.

33. Ristagno G, Sun S, et al. Effects of epinephrine and vasopressin on cerebral microcirculatory flows during and after cardiopulmonary resuscitation*. Crit Care Med 2007;35(9):2145-2149. DOI: 10.1097/01. CCM.0000280427.76175.D2.

34. Ristagno G, Tang W, et al. Epinephrine reduces cerebral perfusion during cardiopulmonary resuscitation*. Crit Care Med 2009;37(4):1408-1415. DOI: 10.1097/CCM.0b013e31819cedc9.

35. Di Battista AP, Rhind SG, et al. Inflammatory cytokine and chemokine profiles are associated with patient outcome and the hyperadrenergic state following acute brain injury. J Neuroinflammation 2016;13(1): 1-14. DOI: 10.1186/s12974-016-0500-3.

36. Cruickshank JM, Neil-Dwyer G, et al. Reduction of stress/ catecholamine-induced cardiac necrosis by beta 1-selective blockade. The Lancet 1987;2(8559):585-589. DOI: 10.1016/S0140-6736(87) 92984-9.

37. Patel MB, McKenna JW, et al. Decreasing adrenergic or sympathetic hyperactivity after severe traumatic brain injury using propranolol and clonidine (DASH After TBI Study): study protocol for a randomized controlled trial. Trials 2012;13(1):177. DOI: 10.1186/1745-621513-177.

38. Alali AS, McCredie VA, et al. Beta blockers for acute traumatic brain injury: a systematic review and meta-analysis. Neurocrit Care 2014;20(3):514-523. DOI: 10.1007/s12028-013-9903-5.

39. Alali AS, Mukherjee $K$, et al. Beta-blockers and Traumatic Brain Injury. Annals of Surgery 2017;266(6):952-961. DOI: 10.1097/ SLA.0000000000002286.
40. Chen $Z$, Tang $L$, et al. Therapeutic effect of beta-blocker in patients with traumatic brain injury: A systematic review and metaanalysis. Crit Care Med 2017;41(C):240-246. DOI: 10.1016/j.jcrc.2017. 05.035

41. Ahl $\mathrm{R}$, Thelin $\mathrm{EP}$, et al. $\beta$-Blocker after severe traumatic brain injury is associated with better long-term functional outcome: a matched case control study. Eur J Trauma Emerg Surg 2017;43(6):783-789. DOI: 10.1007/s00068-017-0779-5.

42. Ahl R, Sjolin G, et al. Does early beta-blockade in isolated severe traumatic brain injury reduce the risk of post traumatic depression? Injury 2017;48(1):101-105. DOI: 10.1016/j.injury.2016.10.041.

43. Ahl R, Barmparas G, et al. Does Beta-Blockade Reduce the Risk of Depression in Patients with Isolated Severe Extracranial Injuries? World J Surg 2017;41(7):1801-1806. DOI: 10.1007/s00268-017-3935-5.

44. Naredi S, Eden E, et al. A standardized neurosurgical neurointensive therapy directed toward vasogenic edema after severe traumatic brain injury: clinical results. Intensive Care Med 1998;24(5):446-451. DOI: 10.1007/s001340050594.

45. Stocchetti N, Maas AIR. Traumatic Intracranial Hypertension. N Engl J Med 2014;370(22):2121-2130. DOI: 10.1056/NEJMra1208708.

46. Muizelaar JP, Marmarou A, et al. Adverse effects of prolonged hyperventilation in patients with severe head injury: a randomized clinical trial. J Neurosurg 1991;75(5):731-739. DOI: 10.3171/ jns.1991.75.5.0731.

47. Andrews PJD, Harris BA, et al. Hypothermia for Intracranial Hypertension after Traumatic Brain Injury. N Engl J Med 2016;374(14):1385-1385. DOI: 10.1056/NEJMc1600339.

48. Hutchinson PJ, Kolias AG, et al. Trial of Decompressive Craniectomy for Traumatic Intracranial Hypertension. N Engl J Med 2016 Sep 22; 375(12):1119-1130. DOI: 10.1056/NEJMoa1605215.

49. Asgeirsson B, Grände PO, et al. A new therapy of post-trauma brain oedema based on haemodynamic principles for brain volume regulation. Intensive Care Med 1994;20(4):260-267. DOI: 10.1007/ BF01708961.

50. Schroeppel TJ, Sharpe JP, et al. Traumatic brain injury and betablockers: not all drugs are created equal. J Trauma Acute Care Surg 2014;76(2):504-509, discussion509. 10.1097/TA.0000000000000104.

51. Ley EJ, Leonard SD, et al. Beta blockers in critically ill patients with traumatic brain injury. J Trauma Acute Care Surg 2018;84(2):234-244. DOI: $10.1097 /$ TA.0000000000001747.

52. Edavettal M, Gross BW, et al. An Analysis of Beta-Blocker Administration Pre-and Post-Traumatic Brain Injury with Subanalyses for Head Injury Severity and Myocardial Injury. Am Surg 2016;82(12): 1203-1208.

53. JS Murry, DM Hoang, et al. Prospective evaluation of early propranolol after traumatic brain injury. J Surg Res 2016;200(1):221-226. DOI: 10.1016/j.jss.2015.06.045.

54. B Zangbar, M Khalil, et al. Metoprolol improves survival in severe traumatic brain injury independent of heart rate control. J Surg Res 2016;200(2):586-592. DOI: 10.1016/j.jss.2015.08.020.

55. Ko A, Harada MY, et al. Early propranolol after traumatic brain injury is associated with lower mortality. J Trauma Acute Care Surg 2016;80(4):637-642. DOI: 10.1097/TA.0000000000000959.

56. Mohseni S, Talving P, et al. The Effect of $\beta$-blockade on Survival After Isolated Severe Traumatic Brain Injury. World J Surg April 2015; 1-8. DOI: 10.1007/s00268-015-3039-z.

57. Mohseni $S$, Talving $P$, et al. Preinjury $\beta$-blockade is protective in isolated severe traumatic brain injury. J Trauma Acute Care Surg 2014;76(3):804-808. DOI: 10.1097/TA.0000000000000139.

58. Bukur M, Mosheni S, et al. Efficacy of beta-blockade after isolated blunt head injury. J Trauma 2012;72(4):1013-1018. DOI: 10.1097/ TA.0b013e318241bc5b.

59. Schroeppel TJ, Fischer PE, et al. Beta-Adrenergic Blockade and Traumatic Brain Injury: Protective? J Trauma 2010;69(4):776-782. DOI: 10.1097/TA.0b013e3181e981b8.

60. Inaba K, Teixeira PGR, et al. Beta-Blockers in Isolated Blunt Head Injury. J Am Coll Surg 2008;206(3):432-438. DOI: 10.1016/ j.jamcollsurg.2007.10.005. 
61. Cotton BA, Snodgrass KB, et al. Beta-Blocker Exposure is Associated With Improved Survival After Severe Traumatic Brain Injury. J Trauma 2007;62(1):26-35. DOI: 10.1097/TA.0b013e31802d02d0.

62. Arbabi S, Campion EM, et al. Beta-Blocker Use is Associated With Improved Outcomes in Adult Trauma Patients. J Trauma 2007;62(1):56-62. DOI: 10.1097/TA.0b013e31802d972b.

63. Di Battista AP, Rhind SG, et al. Inflammatory cytokine and chemokine profiles are associated with patient outcome and the hyperadrenergic state following acute brain injury. J Neuroinflammation 2016;13(1) 1-14. DOI: 10.1186/s12974-016-0500-3.

64. Di Battista AP, Rizoli SB, et al. Sympathoadrenal Activation is Associated with Acute Traumatic Coagulopathy and Endotheliopathy in Isolated Brain Injury. Shock 2016;46:96-103. DOI: 10.1097/SHK.0000000000000642

65. Riordan WP, Cotton BA, et al. Blocker Exposure in Patients With Severe Traumatic Brain Injury (TBI) and Cardiac Uncoupling. J Trauma 2007;63(3):503-510. DOI: 10.1097/TA.0b013e3181271c34. 